\author{
Chirurgia (2020) 115: 261-266 \\ No. 2, March - April \\ Copyright@ Celsius \\ http://dx.doi.org/10.21614/chirurgia.115.2.261
}

\title{
Laparoscopic Approach of Primary Hydatid Cyst of the Pancreas - Case Report and Literature Review
}

\author{
Alin Vasilescu, Eugen Tarcoveanu, Felicia Crumpei, Mihaela Blaj, Valentin Bejan, Costel Bradea
}

First Surgical Clinic, St Spiridon University Hospital, Gr. T. Popa University of Medicine and Pharmacy lasi, Romania

Corresponding author:

Professor Eugen Tarcoveanu

Department of General Surgery

St Spiridon University Hospital

Faculty of Medicine

"Grigore T. Popa" University of Medicine

and Pharmacy, lasi, Romania

E-mail: etarcov@yahoo.com

\section{Rezumat}

\section{Abord laparoscopic în localizarea primară pancreatică a chistului hidatic - prezentare de caz și review al literaturii}

Implicarea pancreasului în chistul hidatic este excepțională, chiar şi în țările în care boala hidatică este endemică.

Prezentare de caz: Descriem cazul unei paciente de sex feminin, în vârstă de 63 de ani, cu chist hidatic pancreatic. Diagnosticul a fost dificil, deoarece prezentarea este cea a unui chist retrogastric cu caracteristici radiologice nu foarte sugestive. Am efectuat o explorare laparoscopică a cavității abdominale şi am descoperit o formațiune chistică retrogastrică dezvoltată din corpul pancreatic. Tratamentul chirurgical a constat în punctie, evacuarea proligerei, spălare cu ser hipertonic, perichistul a fost parțial excizat şi cavitatea restantă a fost drenată. Pacienta a fost externată în ziua 5 postoperator. Controlul efectuat la 6,12 şi 24 de luni nu a arătat apariția unei recidive. Totodată facem şi un review al literaturii, în care discutăm despre dificultățile diagnostice şi terapeutice ale acestei rare localizări a chistului hidatic.

Concluzii: Chistul hidatic este o cauză rară a unei formațiuni chistice pancreatice şi care ar trebui inclusă în diagnosticul diferențial al chisturilor pancreatice, în special în zonele endemice. Chirurgia rămâne în continuare cea mai eficientă opțiune de tratament. Abordul laparoscopic este fezabil şi sigur, dar necesită o echipă instruită cu experiență în chirurgia minim invazivă.

Cuvinte cheie: pancreas, chist hidatic, leziuni chistice pancreatice, laparoscopie 


\section{Abstract}

The pancreatic localization of the hydatid cyst is exceptional, even in countries where hydatid disease is considered endemic.

Case report: We describe a female patient, 63 years old, with hydatid cyst of the pancreas. The diagnosis was difficult because the presentation was that of an epigastric cyst of unknown origin, with no suggestive radiological and ultrasonography features. We performed a laparoscopic exploration of abdominal cavity which revealed a retrogastric cystic mass developed from the pancreatic body. The surgical treatment consisted in puncture, evacuation of proligera, lavage with hypertonic serum, partial excision of the pericyst and drainage of the cavity. The postoperative course was uneventfull and the patient was released after 5 days. The follow-up at 6,12 and 24 month did not show relapse. Through this observation and a review of the literature, we discuss the diagnostic and therapeutic difficulties of this rare localization of the hydatid cyst.

Conclusion: Hydatid cyst is a rare cause of a cystic lesion of the pancreas, especially in endemic areas. Surgery still remains the most effective treatment option. Laparoscopic approach is feasible and secure but requires a trained team with experience in minimally invasive surgery.

Key words: pancreas, hydatid cyst, pancreatic cystic lesions, laparoscopy

\section{Introduction}

Hydatid cyst is a public health problem in endemic countries. The liver and lungs are the most common locations of this parasitic disease, the pancreatic hydatid cyst being considered a very rare occurrence. The clinical symptomatology is often insidious and scarce, being dominated either by non-specific abdominal pain and or signs and symptoms related to the mass effect. The hydatid cyst of the pancreas can pose both a diagnostic and treatment challenge, especially in order to avoid contamination and spillage intraoperatively. Although a perforation, a hemorrhage or a fistulation, thus leading to an inflammatory syndrome or recurrent abdominal pain, can be revealing towards a diagnosis, they represent serious complications and causes for morbidity and mortality. Due to this etiology, it is mandatory for the patient to follow postoperatively anti echinococcus therapy (1-3).

\section{Case Report}

We present the case of a 63-year-old female patient, with no medical history, hospitalized for epigastric pain associating nausea and vomiting, with insidious onset over the past 2 months and increased severity of the symptoms 3 days prior to admission. The clinical exam revealed a patient with a good general condition, with a palpable sensitive epigastric cystic mass. Also worth mentioning was the absence of clinical jaundice.

The laboratory data revealed slightly above normal values of serum amylase and lipase, with normal liver and kidney function panels. CEA and CA 19-9 levels were normal and hydatid serology was negative.

Ultrasonography revealed an enlarged pancreas with a 110/86 mm well-circumscribed cystic mass located at the level of isthmus and body of the pancreas (Fig. 1). There was no dilatation of the Wirsung and common bile duct, with the absence of gallstones. The same aspects were observed at the CT examination performed in gastroenterology service of another hospital, one month prior to the current admission, therefore we only had access to the written report. Also, at the time of admission, endoscopic US examination was unavailable in our hospital. 

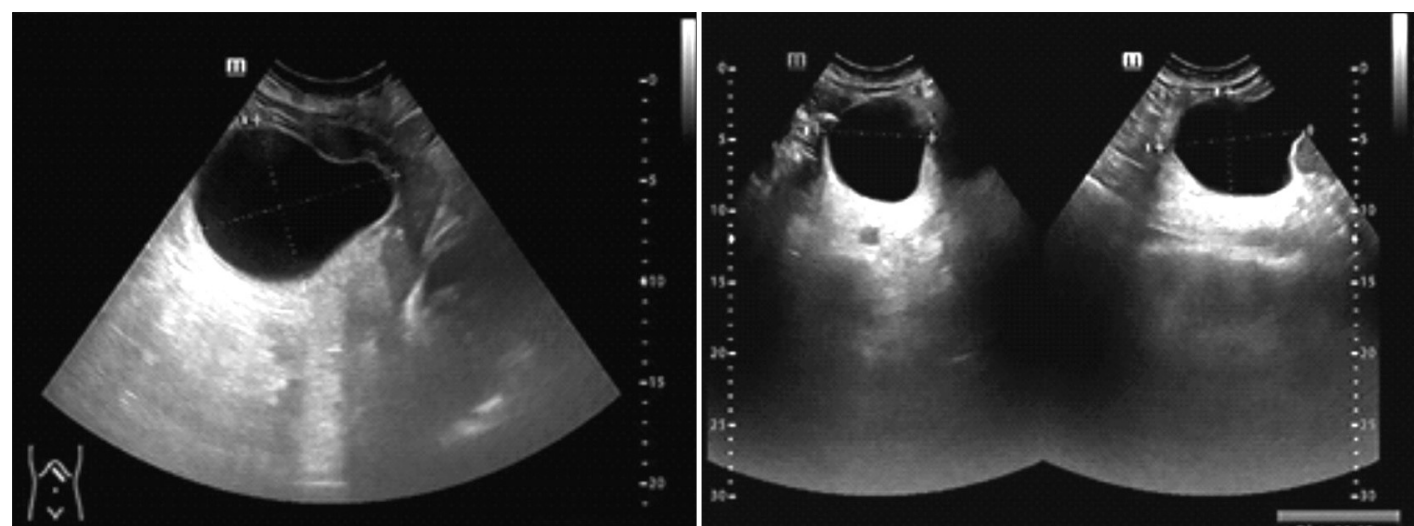

Figure 1. Abdominal ultrasonography - well-circumscribed hypoechogenic mass with dimensions 110/86 mm, located retrogastric developed from pancreatic body

The preoperative diagnosis was that of an epigastric cyst, with no specific radiological and laboratory features, apart from the possible pancreatic origin.

The final diagnosis was intraoperative. We performed a laparoscopic exploration of abdominal cavity which revealed a retrogastric cystic mass, macroscopically resembling a hydatid cyst developed from pancreatic body. The surgical treatment consisted in puncture, evacuation of proligera, lavage with hypertonic serum, pericyst was partially excised and drainage of the cavity (Fig. 2). The drain was removed on postoperative day 4, when serum amylase and lipase levels returned to normal. The patient was discharged after 5 postoperative days.

The pathology report confirmed the hydatid cyst diagnosis. Postoperatively, the patient underwent anti echinoccocus treatment, i.e. albendazole in the dose of $10 \mathrm{mg} / \mathrm{kg} / \mathrm{day}$ for 2 months. The follow-up at 6, 12 and 24 month did not show relapse.

\section{Discussion}

The hydatid cyst is a parasitic disease caused by Echinococcus granulosus. Primary pancreatic localization of the hydatid cyst is rare with an incidence between $0.14 \%$ to $0.2 \%$. Pancreatic involvement is thought to appear mainly because of hematogenous dissemination, although other possible spread mechanism have been described such as lymphatic or direct passage from the intestine (1).

Our clinic has an experience of over 200 hydatidosis cases operated in the last 15 years, in which pancreatic localization was found only in 3 cases. In one case it was associated with other localizations (hepatic, pancreatic and splenic hydatid cyst) (2) and in the other 2 cases it was a single primary pancreatic location (body pancreatic hydatid cyst operated by open approach in the early 90 's and this case).

The single primary pancreatic location is discovered in most of cases $(3,4)$. The most frequent location of pancreatic hydatid cyst is in head of the pancreas followed by body and tail of the pancreas (5).

The size of the hydatid pancreatic cyst can vary from a few millimeters to several centimeters and it has an intra parenchymal development in $35 \%$ of the cases and peripheral in $65 \%$ of the cases (6). In our case the pancreatic cyst was a peripheral development.

In most cases hydatid cysts are asymptomatic. The clinical symptomatology is unspecific, variable and dependent on the size, location of the cyst and potential complications as in our case. The main symptoms include abdominal pain (most of cases) in the upper abdomen, vomiting and palpable cystic mass, along with other symptoms due to the mass effect (7). Some complications may occur: obstructive jaundice due to compression or rupture into the common bile duct, cholangitis, 

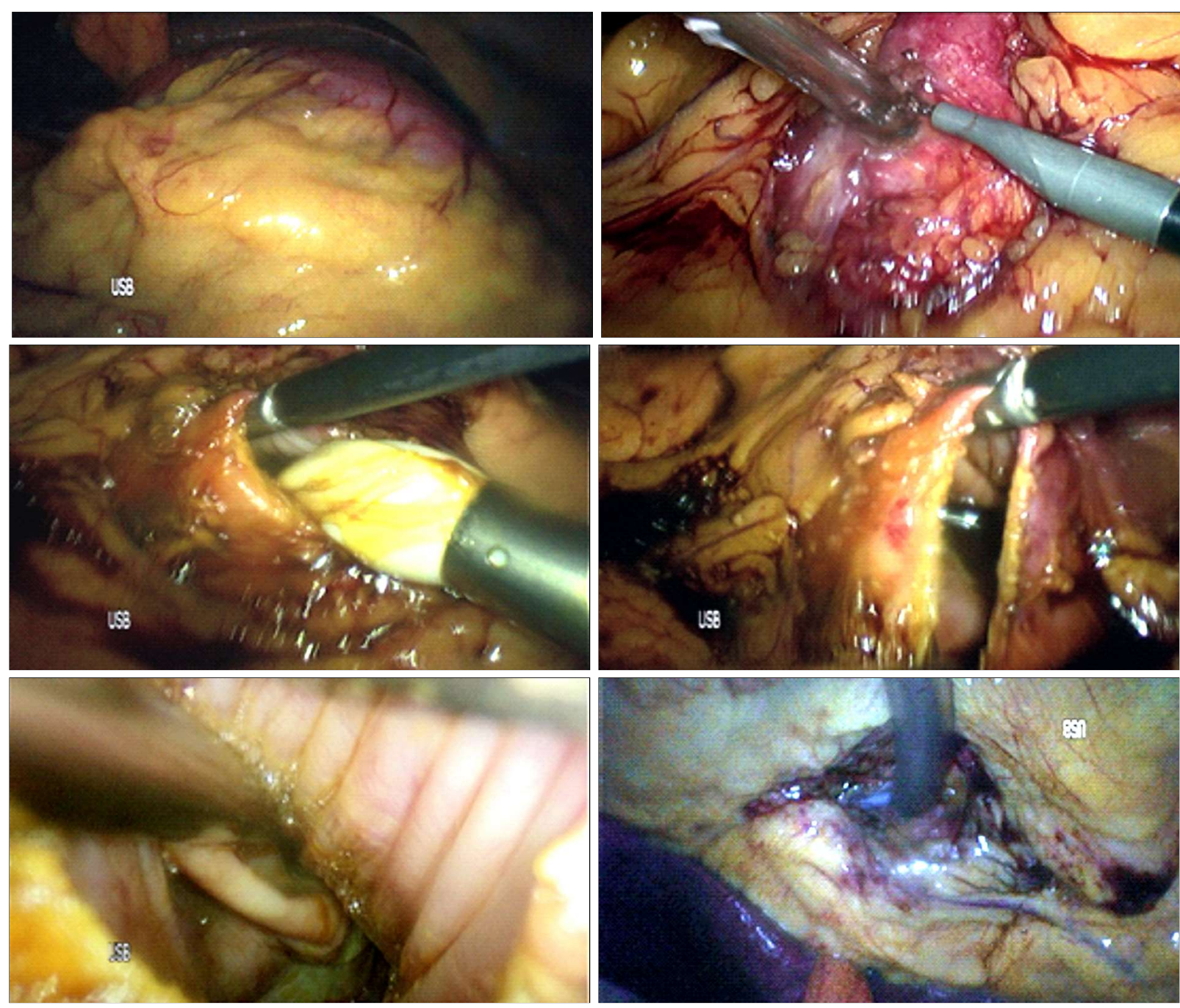

Figure 2. Intraoperative view - surgical treatment of hidatid pancreatic cyst: puncture, evacuation of proligera, partially pericystectomy and drainage of the cavity

pancreatitis, pancreatic abscess and pancreatic fistula due to erosion of pancreatic ducts which can also be responsible for recurrent acute pancreatitis. The opening of the cyst in the digestive tract is possible yet exceptional (8).

Preoperative diagnosis is very difficult. Ultrasonography is useful for detecting cyst membranes and can detect the floating endocyst. Endoscopic ultrasound can be valuable for imagistic diagnosis as well as for suction and study of the cystic fluid, especially for cephalic localizations (9). The WHO classification based on ultrasound criteria has been progressively preferred to other classifications. It reversed two stages in the priorly used Gharbi classification to reflect the natural history of hydatid disease (10).

$\mathrm{CT}$ of the abdomen can reveal a cystic mass, sometimes with an undulating membrane and a multiple degenerating daughter cysts within the mother cyst may alert regarding the possibility of pancreatic echinococcosis. The presence of another hydatid location, the detachment of cystic membrane and the presence of arcuate calcifications are in favor of the hydatid origin. Radiological examinations alone may not be sufficient to diagnose primary pancreatic hydatid disease (11).

Diagnostic fine needle aspiration is formally 
contraindicated because of the risk of retro- or intra-peritoneal dissemination. The catheterization of the Wirsung by endoscopic retrograde cholangiopancreatography (ERCP) is recommended only in cases which present complications. Numerous laboratory tests are available for detecting specific serum antibodies and echinococcal antigens, such as ELISA test which has good sensitivity, specificity and diagnostic accuracy over $90 \%$ $(12,13)$.

The differential diagnosis of pancreatic hydatid cyst is challenging because can mimic more common cystic pancreatic lesions: pseudocysts, mucinous cystadenoma, cystadenocarcinoma, intraductal papillary mucinous neoplasms and congenital or post-traumatic cysts. Pancreatic hydatid cyst should be considered in diagnosis not only in endemic area, a past history of traveling or immigration suspect the possibility the presence of hydatid disease $(14,15)$.

Surgery is a treatement of choice for hidatid cyst of the pancreas. The preferred treatment may consist of surgical excision or evacuation of cyst contents with partial cystectomy and the cavity should be washed with hypertonic saline solutions as we performed in our case.

In all cases, if the hydatid nature of a cystic mass of the pancreas is suspected, protection of the operating field and the abdominal wall with a scolicide solution is mandatory.

The presence of a fistula requires a radical resection depending on localization of the lesion: left pancreatectomy is indicated for the body or tail pancreatic hidatid cyst and for cephalic pancreatic hidatid cyst a jejunal cyst anastomosis on a Y-loop or suture of the Wirsung canal on a trans-duodeno-papillary stent can be performed. The choice will depend on the size of the fistula. The pancreaticoduodenectomy is a disproportionate surgical gesture toward of benign parasitic disease (16).

In selected cases laparoscopic treatment may be feasible, even radical resections can be performed (17). Also, after any surgery of the pancreas, pseudocyst formation may occur (11).
Medical therapy is useful when it is combined with surgery. Drug treatment with Albendazole for a period of 8-12 weeks before and after the procedure is the most effective and reduces the risk of recurrence (18). In our case, we started albendazole in the postoperative period.

PAIR (puncture, aspiration, injection of a scolicidal agent, reaspiration) has also been reported in the literature for cases with high surgical risk with lower rates of recurrence and mortality but the treatment must be combined with albendazole (19).

\section{Conclusions}

Hydatid cyst is rare with preoperative diagnosis difficult and must be included in the differential diagnosis of cystic lesion of the pancreas. He can cause severe complications if not treated. Surgery still remains the most effective treatment option. Laparoscopic approach is feasible and secure but requires a trained team with experience in minimally invasive surgery.

\section{Conflict of Interest}

The authors declare no conflicts of interests.

\section{References}

1. Soin $P$, Sharma $P$, Kochar PS. Pancreatic echinococcosis. Proc (Bayl Univ Med Cent). 2019;32(1):85-7;

2. Tarcoveanu E, Dimofte G, Bradea C et al. Multiple peritoneal hydatid disease after rupture of a multivesicular hepatic hydatid cyst. Case report. J Gastrointestin Liver Dis. 2006;15(3):301-5;

3. Makni A, Jouini M, Kacem M, Safta Z. Acute pancreatitis due to pancreatic hydatid cyst: a case report and review of the literature. World Journal of Emergency Surgery. 2012;7(1):7;

4. Bouasker I, Zoghlami A, Ben Achour $\mathrm{J}$ et al. Hydatid cysts of the pancreas, report of two cases Tunis Med. 2009;87(2):155-8;

5. Alsaid B, Alhimyar M, Rayya F. Pancreatic Hydatid Cyst Causing Acute Pancreatitis: A Case Report and Literature Review. Case Rep Surg. 2018;2018:9821403;

6. Khiari A, Mzali R, Ouali M et al. Hydatid cyst of the pancreas. Apropos of 7 cases Ann Gastroenterol Hepatol (Paris). 1994;30(3):87-91;

7. Agudelo Higuita NI, Brunetti E, McCloskey CJ. Clin Microbiol. 2016; 54(3):518-23;

8. Arnaud A, Sarles JC, Belkhodja C, Larabi B. Hydatid cyst of the pancreas. Apropos of 2 cases Chirurgie. 1991;117(8):607-11;

9. Hiremath B, Subramaniam N, Boggavarapu M. Primary pancreatic hydatid cyst: an unexpected differential diagnosis. BMJ Case Rep. 2015; 2015. pii: bcr2015211377; 
10. Mirabile E, Solomon N, Fields PJ, Macpherson CNL. Progress towards international adoption of the World Health Organization ultrasound classification of cystic echinococcosis. Acta Trop. 2019; 189:6-9;

11. Chinya A, Khanolkar A, Kumar J, Sinha SK. Isolated hydatid cyst of the pancreas masquerading as pancreatic pseudocyst. BMJ Case Rep. 2015 11;2015. pii: bcr2015211307;

12. Akbulut S, Yavuz R, Sogutcu N et al. Hydatid cyst of the pancreas: report of an undiagnosed case of pancreatic hydatid cyst and brief literature review. World J Gastrointest Surg. 2014 6(10):190-200;

13. Sbihi Y, Rmiqui A, Rodriguez-Cabezas MN, Orduña A, RodriguezTorres A, Osuna A. Comparative sensitivity of six serological tests and diagnostic value of ELISA using purified antigen in hydatidosis. J Clin Lab Anal. 2001;15(1):14-18

14. Lemmer ER, Krige JE, Price SK, Girdwood AH Hydatid cyst in the head of the pancreas with obstructive jaundice. J Clin Gastroenterol. 1995 Mar; 20(2):136-8;

15. Ozmen MM, Moran M, Karakahya M, Coskun F. Recurrent acute pancreatitis due to a hydatid cyst of the pancreatic head: a case report and review of the literature. JOP. 2005;6(4):354-8;

16. Balik $A A$. Surgical treatment of hydatid disease of the liver: review of 304 cases. Archives of Surgery. 1999;134(2):166-9;

17. Revoredo Rego F, De Vinatea De Cárdenas J, Reaño Paredes G et al. Hydatid cysts in pancreas: laparoscopic approach Rev Gastroenterol Peru. 2016;36(3):264-8;

18. Lo Monte A, Maione C, Napoli N. Renal hydatidosis. Discussion of a clinical case complicated by post acute pancreatitic cyst. Minerva Chirurgica. 1998;53(7-8):659-62.

19. Yattoo N, Khuroo S, Zargar S et al. Percutaneous drainage of the pancreatic head Hydatid cyst with obstructive jaundice. J Gastroenterol Hepatol 1999;14:931-4. 